J. Clin. Chem. Clin. Biochem.

Vol. 23, 1985, pp. $845-850$

\title{
Optimization of the Urinary Acid $\alpha$-Glucosidase Determination
}

\author{
By F. Ceriotti, L. Barenghi, M. Pontillo, M. Murone and P. A. Bonini \\ Istituto Scientifico S. Raffaele, Laboratorio Analisi, Milano, Italy
}

(Received March 11/September 23, 1985)

Summary: The optimization of the method for acid $\alpha$-glucosidase determination (EC 3.2.1.3) in human urines, employing the synthetic substrate 4-nitrophenyl- $\alpha-D$-glucopyranoside, is reported. Storage conditions of the specimens and their pretreatment were particularly investigated. The precision of the whole analytical procedure (including gel filtration) is good (within-run $\mathrm{CV}=7.4 \%$ for normal samples and $3.7 \%$ for elevated ones). The correlation with the method using maltose as substrate is excellent ( $y=-0.01+0.13 x ; r=$ 0.9893).

\section{Optimierung der Bestimmung von saurer $\alpha$-Glucosidase im Harn}

Zusammenfassung: Die Optimierung der Methode zur Bestimmung von saurer $\alpha$-Glucosidase (EC 3.2.1.3) im Harn des Menschen mit 4-Nitrophenyl- $\alpha-D$-glucopyranosid als Substrat wird beschrieben. Probenverwahrung und Probenvorbereitung wurden besonders geprüft. Die Präzision des gesamten analytischen Verfahrens (einschließlich Gelfiltration) ist gut. Der VK in der Serie betrug 7,4\% für Proben im Referenzbereich, 3,7\% bei erhöhter katalytischer Konzentration. Die Korrelation mit der Methode mit Maltose als Substrat ist hervorragend $(y=0,01+0,13 x ; r=0,9893)$.

\section{Introduction}

Acid $\alpha$-glucosidase (EC 3.2.1.3) is a lysosomal enzyme present in a wide variety of tissues (liver, kidney, gut). This enzyme is normally present at low levels in human urine as a result of normal turnover and lysis of tubular cells; since it is practically absent from plasma, its increase in urine appears to be a sensitive indicator for tubular damage $(1-6)$. Acid $\alpha$-glucosidase activity has been measured either photometrically, with maltose as a substrate, or fluorimetrically utilizing the synthetic substrate 4-methyl-umbelliferyl $=\alpha-\hat{D}$-glucopyranoside (7). The glucose released from maltose was assayed with $o$-toluidine (8) or enzymatically with glucose oxidase (9) or hexokinase (10). While the $o$-toluidine method must be considered to be obsolete, the maltase contamination is a major disadvantage of the glucose oxidase method; furthermore both these methods are rather complicated and time consuming as is the maltose and hexokinase method (11). The use of the 4-nitrophenyl- $\alpha$ - $D$-glucopyranoside as a synthetic substrate has been proposed in preliminary experiments (12). In this study, we present an optimization of this method, characterized by great simplicity and good specificity. Optimal conditions for the storage of urines and their preliminary treatment are also illustrated.

\section{Materials and Methods}

Sephadex G-25 fine was obtained from Pharmacia; 4-nitrophenyl-- $D$-glucopyranoside (cat. No. 73673) and $p$-nitrophenol (cat. No. 104-1) were purchased from Fluka; 2-amino-2-methyl1-propanol hydrochloride from Sigma Chemical Co. (cat. No. 5888); Minicon concentrator B 15 was obtained from Amicon Corp. (Danvers MA 01923); Visking dialysis tubing (type 8/32, cat. No. 44104) was purchased from Serva, Heidelberg. Test Combination Gluco-quant (cat. No. 245178) was obtained from Boehringer Mannheim GmbH. All other chemicals were analytical grade from Merck, Darmstadt, Germany. 


\section{Subjects}

Urine specimens (from patients presenting with advanced chronic renal failure, and from renal transplant cases) selected to cover abnormal ranges of $\alpha$-glucosidase activity were obtained from our hospital clinical laboratory. Specimens from carefully selected healthy subjects were collected to cover the normal ranges and for preliminary reference values. Healthy subjects (males and females ages 20-50 years) were judged from physical examination and routine laboratory tests (normal urinalysis and creatinine clearance); they had no illness and were not under medications, there was no history of renalgenital-urinary tract disorders, and none was using drugs known to affect enzyme release in urine.

\section{Urine collection}

Acid $\alpha$-glucosidase was determined in random morning or. in timed $(8-12 \mathrm{~h})$ urines; bacterial growth was avoided by adding $5 \mathrm{ml}$ of $29.6 \mathrm{mmol} / \mathrm{l}$ sodium methiolate solution to the containers (13). Samples were stored at $4^{\circ} \mathrm{C}$ and assayed within $24 \mathrm{~h}$ of collection.

\section{Urine treatment}

a-Glucosidase is separated from possible inhibitors by gel filtration. Plastic columns $20 \mathrm{~cm}$ high, $10 \mathrm{~mm}$ diameter (Bio Rad Econo Columns), containing $7.8 \mathrm{ml}$ of Sephadex G-25 fine previously swollen in a $\mathrm{NaCl} 154 \mathrm{mmol} / \mathrm{l}$ solution, were used. $1 \mathrm{ml}$ of the supernatant of the centrifuged urines $(10$ minutes at $1200 \mathrm{~g}$ ) is applied to the column. When the sample is completely absorbed on the gel, add $1.5 \mathrm{ml}$ of $\mathrm{NaCl} 154 \mathrm{mmol} / \mathrm{l}$ solution, allow the column to drain and discard the eluate $(2.5 \mathrm{ml})$. Add $2 \mathrm{ml}$ of the elution solution to the column, allow to drain completely collecting the eluate $(2 \mathrm{ml})$ containing $\alpha$-glucosidase. Wash the column with a solution $(30 \mathrm{ml})$ containing $\mathrm{NaCl} 154$ $\mathrm{mmol} / \mathrm{l}$ and $\mathrm{NaN}_{3} 3.1 \mathrm{mmol} / \mathrm{l}$. The columns, filled with $\mathrm{NaCl}$ $\mathrm{NaN}_{3}$ solution can be stored at room temperature for several months and reused for many samples. Alternatively urine specimens are dialysed according to Ceriotti et al. (13).

Assay of acid $\alpha$-glucosidase activity

\section{Reagents}

A) Acetate buffer, $0.13 \mathrm{~mol} / \mathrm{l}, \mathrm{pH} 4.2$ sodium acetate acetic acid

$\mathrm{KCl}$

* final concentration in the reaction mixture

$0.1 \mathrm{~mol} / \mathrm{I}^{*}$ $0.03 \mathrm{~mol} / \mathrm{l}^{*}$ $0.01 \mathrm{~mol} / \mathrm{l}^{*}$

Store at room temperature for about one month.

B) Substrate: 4-nitrophenyl- $\alpha-D$-glucopyranoside $10 \mathrm{mmol} / \mathrm{l}$ (final concentration in the reaction mixture) in acetate buffer (A). Prepare immediately before use.

C) 2-Amino-2-methyl-propanol buffer, $0.75 \mathrm{~mol} / 1, \mathrm{pH} 10.25$ Titrate to $\mathrm{pH} 10.25$ with $\mathrm{NaOH} 6 \mathrm{~mol} / \mathrm{l}$

D) Working standard solution, $100 \mu \mathrm{mol} / 1$ Immediately before use dilute the $10 \mathrm{mmol} / \mathrm{l} \mathrm{p}$-nitrophenol stock standard solution 100 fold, with saline.

\section{Procedure}

Alpha-glucosidase hydrolyses the substrate $p$-nitrophenyl- $\alpha-D$ glucopyranoside, releasing $p$-nitrophenol, which is intensely coloured under alkaline conditions.

Column eluates and substrate are separately preincubated about $15 \mathrm{~min}$ at $37^{\circ} \mathrm{C}$. Then $0.5 \mathrm{ml}$ of eluate (in duplicate) is added to $0.5 \mathrm{ml}$ of substrate, mixed and incubated at $37^{\circ} \mathrm{C}$.
Aliquots of $0.25 \mathrm{ml}$ of the reaction mixture are collected at 0 (sample blank) 30 and 60 minutes and added to $1 \mathrm{ml}$ of 2 amino-2-methyl-1-propanol buffer to stop the reaction. The absorbance is measured at $405 \mathrm{~nm}$ against a reagent blank $(0.125 \mathrm{ml}$ saline, $0.125 \mathrm{ml}$ substrate, $1 \mathrm{ml}$ 2-amino-2-methyl-1propanol). With each set of determinations it is advisable to run a standard containing $12.5 \mathrm{nmol}$ of $p$-nitrophenol, 0.125 $\mathrm{ml}$ of saline solution, $0.125 \mathrm{ml}$ of working standard solution, and $1 \mathrm{ml}$ of 2-amino-2-methyl-1-propainol, which is measured against a reagent blank $(0.25 \mathrm{ml}$ saline and $1 \mathrm{ml} \mathrm{2-amino-2-}$ methyl-1-propanol).

\section{Calculation}

$\alpha$-glucosidase activity $\mathrm{U} / \mathrm{l}=\frac{\left(\mathrm{A}-\mathrm{A}_{0}\right) \times 8 \times 2}{\mathrm{~A}_{\mathrm{st}} \times 60} \times 12.5$

where

$\mathrm{U} / \mathrm{l}=\mu \mathrm{mol} / \mathrm{min} \cdot 1$

$\mathrm{A}=$ (absorbance after $60 \min +2 \times$ absorbance after $30 \mathrm{~min}) / 2$

$\mathrm{A}_{0}=$ absorbance at time 0

$\mathrm{A}_{\mathrm{st}}=$ absorbance of the standard

$60=$ min, incubation time

8 = factor to relate the value to $1 \mathrm{ml}$ of eluate

$2=$ dilution factor due to column elution

$12.5=$ nmol of $p$-nitrophenol in the standard

The urinary activity concentration of $\alpha$-glucosidase can be expressed in $\mathrm{U} / \mathrm{mmol}$ creatinine.

\section{Other Methods}

As reference method, we adopted the method described by Kochmann et al. (11), using maltose as substrate and hexokinase to determine the reaction product. Urinary creatinine concentrations were measured by the alkaline picrate reaction (14). Neutral glucosidase activity was assayed by the method described by Kochmann et al. (11).

\section{Results and Discussion}

Pretreatment, Storage and Expression of Results

\section{Effect of gel filtration}

Urine is a very unfavorable environment for enzymes; wide variations in hydrogen ions, variable salt concentrations and unpredictable presence of different inhibitors and activators interfere with the assay of urinary enzymes. While dialysis and ultrafiltration are applied for inhibitors, activators or interfering chromogen removal in many enzymatic determinations $(15-18)$, we preferred the gel filtration because it is more practical (less time consuming, no need of trained personel, reproducible results) in clinical laboratories (16). Moreover this procedure permits the preparation of a single specimen for the assay of multiple enzymes (15). By collecting the elution volume from 2.5 to $4.5 \mathrm{ml}$ as described, $97 \%$ of the total enzymatic activity is recovered from the column. The 
effect of the gel filtration was assayed by comparing the enzymatic activity of 19 non-filtered urines (without glucose) and their eluates: as seen in table 1 , the activity was higher in the eluate than in the urine in only two cases. In the other cases a mean loss of $9 \%$ occurred after gel filtration, probably due to removal of activators (16). Possible loss of enzymatic activity in gel filtration was tested in the following experiments: on 7 urines dialysed according to Ceriotti et al. (13), acid $\alpha$-glucosidase was measured before and after gel filtration; as we can see in table 2, no loss of the enzyme occurred during gel filtration in any samples. The mean recovery of $\mathbf{9 6 . 2}$ $\pm 2.5 \%$ is in good agreement with the value expected.

As glucose is an inhibitor of acid $\alpha$-glucosidase activity (17), we assayed enzymic acitivity on 3 urine specimens with different glucose contents, before and after gel filtration. Data reported in table 3 confirm the inhibition by glucose and reinforce the need of gel filtration for its removal.

\section{Results in timed versus random collected urines}

We assayed 143 specimens from hospital patients and healthy adult subjects for acid $\alpha$-glucosidase activity. Figure 1 shows the excellent correlation $(y=7.5+$ $9.25 \mathrm{x}, \mathrm{r}=0.9199)$ between results expressed in $\mathrm{mU} /$ $\min (x)$ and $U / \mathrm{mmol}$ of creatinine $(y)$. The correlation is sufficiently good also in pathologic specimens. We therefore propose the use of random urine samples, thus avoiding unpractical timed collections of urines (19).

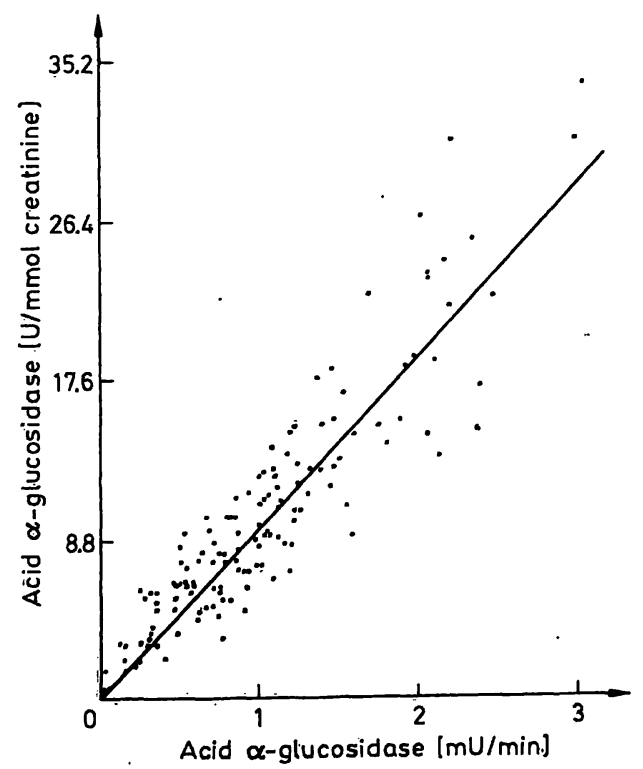

Fig. 1. Correlation between catalytic activity expressed in $\mathrm{mU} / \mathrm{min}(\mathrm{x})$ and $\mathrm{U} / \mathrm{mmol}$ creatinine $(\mathrm{y})$.
Tab. 1. Effect of gel filtration on acid $\alpha$-glucosidase activity.

\begin{tabular}{llll}
\hline Sample & $\begin{array}{l}\text { Non-filtered } \\
\text { urine } \\
(\mathrm{U} / \mathrm{l})\end{array}$ & Eluate & Activity \\
\hline 1 & 1.91 & $(\mathrm{U} / \mathrm{l})$ & $(\%)^{*}$ \\
2 & 2.82 & 2.01 & 105.2 \\
3 & 2.01 & 2.38 & 84.4 \\
4 & 2.74 & 1.81 & 90 \\
5 & 2.51 & 2.54 & 92.7 \\
6 & 5.23 & 2.41 & 96 \\
7 & 2.79 & 5.64 & 107.8 \\
8 & 1.97 & 2.65 & 94.5 \\
9 & 2.36 & 1.86 & 94.4 \\
10 & 4.95 & 2.10 & 88.9 \\
11 & 0.62 & 4.92 & 99.4 \\
12 & 5.77 & 0.55 & 89 \\
13 & 1.76 & 5.67 & 98 \\
14 & 4.43 & 1.07 & 86 \\
15 & 2.94 & 3.9 & 88 \\
16 & 2.86 & 2.41 & 82 \\
17 & 1.96 & 2.47 & 86 \\
18 & 2.25 & 1.71 & 87 \\
19 & 3.45 & 1.68 & 75 \\
\hline \multirow{2}{*}{ activity \% } & activity on eluate & 2.78 & 81 \\
\hline
\end{tabular}

Tab. 2. Effect of gel filtration on dialysed urine specimens.

\begin{tabular}{llll}
\hline & $\begin{array}{l}\text { Dialysed } \\
\text { urine } \\
(\mathrm{U} / \mathrm{l})\end{array}$ & $\begin{array}{l}\text { Eluate of } \\
\text { dialysed urine } \\
(\mathrm{U} / \mathrm{l})\end{array}$ & $\begin{array}{l}\text { Recovery } \\
(\%)\end{array}$ \\
\hline 1 & 8.61 & 8.51 & 98.84 \\
2 & 4.47 & 4.24 & 94.96 \\
3 & 3.37 & 3.21 & 95.11 \\
4 & 12.18 & 11.41 & 93.68 \\
5 & 7.34 & 7.06 & 96.19 \\
6 & 12.47 & 12.32 & 98.79 \\
7 & 5.93 & 5.86 & 95.95 \\
\hline
\end{tabular}

Tab. 3. Effect of glucose on acid $\alpha$-glucosidase activity.

\begin{tabular}{lllll}
\hline $\begin{array}{l}\text { Urine } \\
\alpha \text {-Gluco- } \\
\text { sidase } \\
(\mathrm{U} / \mathrm{l})\end{array}$ & Glucose & $\begin{array}{l}\text { Eluate } \\
\alpha \text {-Gluco- } \\
\text { sidase } \\
(\mathrm{U} / \mathrm{l})\end{array}$ & Glucose \\
\hline 1 & 5.12 & $\mathrm{~g} / \mathrm{l})$ & 0 \\
2 & 4.86 & 1.43 & 5.24 & 0 \\
3 & 2.55 & 15.7 & 5.21 & 0 \\
\hline
\end{tabular}

\section{Influence of $\mathrm{pH}$ and storage temperature}

We studied the effect of storage temperature and urine $\mathrm{pH}$ on enzyme stability on urine samples immediately eluted, and then stored, in comparison with the same samples, stored in the same conditions and for the same time, without preliminary elution. 
Pooled urines with $\mathrm{pH}$ values of $5.5,6.5$ and 7.5 respectively were divided in two aliquots each, one of which was eluted on the Sephadex column. Both the unfiltered urines and their eluates were then subdivided into several aliquots and stored at different temperatures: $4^{\circ} \mathrm{C},-20^{\circ} \mathrm{C}$ and $-80^{\circ} \mathrm{C}$ for four months. At stated intervals of time the aliquots were analysed (the previously unfiltered urines were filtrated just before the enzymatic analysis). We observed that $-80^{\circ} \mathrm{C}$ is the optimal storage temperature for both urines and eluates of any $\mathrm{pH} .-20^{\circ} \mathrm{C}$ is an unfavorable storage temperature, while the stability of unfiltered urines at $4{ }^{\circ} \mathrm{C}$ is good, at least for 1 month, except at $\mathrm{pH}$ 7.5. To better verify the effect of the urine $\mathrm{pH}$ on $\alpha$-glucosidase activity we divided one urine sample (initially $\mathrm{pH} 5$ ) in various aliquots, which were brought to $\mathrm{pH} 6.5,7.5$ and 8.5 adding $\mathrm{NaOH}$. The specimens were kept at $4{ }^{\circ} \mathrm{C}$ and $37^{\circ} \mathrm{C}$ and assayed after different intervals $(0,2 \mathrm{~h}, 4 \mathrm{~h}$ and $24 \mathrm{~h}$ ). We found that the enzyme is stable up to $\mathrm{pH}$ 6.5 , but for more alkaline $\mathrm{pH}$ values there was a continuous decay of enzyme activity. At $\mathrm{pH} \geqslant 7.5$ there was an immediate denaturation. Thus we consider a urine with $\mathrm{pH} 7.5$ or more as inappropiate for acid $\alpha$-glucosidase determination.

\section{Optimization of the assay}

\section{Effect of salts}

The influence of several different salts $(\mathrm{Zn}$ acetate, $\mathrm{CaCl}_{2}, \mathrm{MgCl}_{2}, \mathrm{Na}_{2} \mathrm{HPO}_{4}, \mathrm{CuCl}, \mathrm{Fe}\left(\mathrm{NH}_{4}\right)_{2}\left(\mathrm{SO}_{4}\right)_{2}$, $\mathrm{KCl}$ ) on $\alpha$-glucosidase activity was investigated, using a $5 \mathrm{mmol} / \mathrm{l}$ final concentration of each salt in acetate buffer; only iron salts and $\mathrm{KCl}$ have an activating effect on enzymatic activity (about $30 \%$ ). As iron salts cannot be used because of the ferric hydrate precipitation when blocking the reaction, $\mathrm{KCl}$ was the only usable salt, as already reported in literature $(11,17)$. The optimal $\mathrm{KCl}$ concentration was 10 $\mathrm{mmol} / \mathrm{l}$ (final concentration in the reaction mixture).

\section{Optimal reaction $p H$}

Using a buffer containing a final concentration of $\mathrm{KCl}$ of $10 \mathrm{mmol} / \mathrm{l}$ at different $\mathrm{pH}$ values $(3.6-5.0)$, we verified the dependence of acid $\alpha$-glucosidase activity on the $\mathrm{pH}$ of the acetate buffer. We found an optimum $\mathrm{pH}$ curve with a maximum between $\mathrm{pH} 4.2$ and 4.6 (fig. 2), which does not significantly differ from the maxima reported by Kochmann et al. (11) (pH 3.8), Kokichi et al. (20) (pH 4.0), and Ceriotti \& Bonini (17) (pH 4.2). We prefer to work at $\mathrm{pH} \mathrm{4.2,}$ which gives a more specific test for acid $\alpha$-glucosidase.

\section{Blockage of the reaction}

The originally prepared $\mathrm{Na}_{2} \mathrm{CO}_{3}$ solution (12) was replaced with 2-amino-2-methyl-1-propanol buffer, because the $\mathrm{Na}_{2} \mathrm{CO}_{3}$ does not completely stop the enzymatic reaction.

\section{Substrate concentration}

Highest acid $\alpha$-glucosidase activity was obtained at the final concentration of $10 \mathrm{mmol} / 1$ of substrate; complete saturation of the enzyme with substrate could not be achieved because of limited solubility of 4-nitrophenyl- $\alpha$ - $D$-glucopyranoside (fig. 3). At the substrate concentration chosen for the routine procedure $(10 \mathrm{mmol} / \mathrm{l})$ an average 78 percent of maximum reaction rate was reached. The Michaelis constant, calculated according to the method of Lineweaver \& Burk, was $3.17 \mathrm{mmol} / \mathrm{l}$ in agreement with Ceriotti et al. (12).

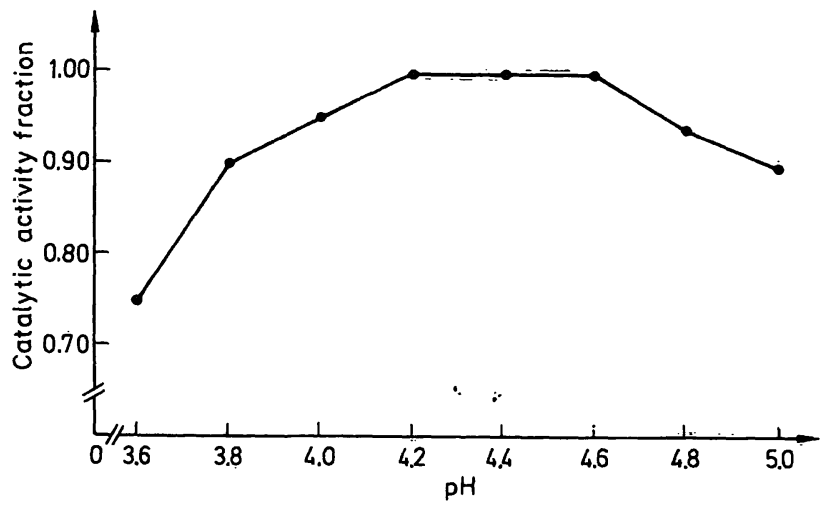

Fig. 2. Effect of $\mathrm{pH}$ on acid $\alpha$-glucosidase activity.

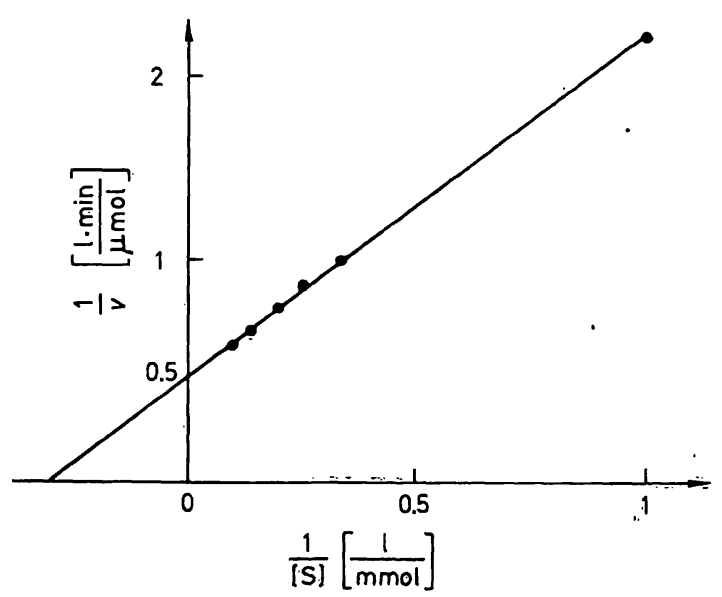

Fig. 3. Effect of substrate concentration on enzymatic activity; Lineweaver \& Burk plot. 


\section{Linearity}

To study the linearity, an artificially high concentration of enzyme was prepared by concentrating a urine pool with a Minicon concentrator B 15. An enzyme concentration was obtained approximately 20 times higher than that of normal urine. In figure 4 the results of the enzymatic activity in such an urine and in its scalar dilutions are reported; despite the relatively low substrate concentration, the linearity of the reaction is good up to $50 \mathrm{U} / \mathrm{l}$. The duration of the enzymic reaction and the absorbance of released $p$-nitrophenol were linearly related up to $25 \mathrm{U} / 1$ between $0 \mathrm{~min}$ and $60 \mathrm{~min}$, and up to $50 \mathrm{U} / \mathrm{l}$ between $0 \mathrm{~min}$ and $30 \mathrm{~min}$.

\section{Precision}

Acid $\alpha$-glucosidase was assayed in quintuplicate for three days on two samples of different acitivites. We found good between-run and within-run coefficents of variation relative to the whole analytical process (tab. 4).

Tab. 4. Between-day and within-day precision.

\begin{tabular}{llrll}
\hline & \multicolumn{2}{l}{ Level I } & \multicolumn{2}{l}{ Level II } \\
& $\mathrm{x}=0.87 \mathrm{U} / \mathrm{l}$ & \multicolumn{2}{l}{$\mathrm{x}=2.0 \mathrm{U} / \mathrm{l}$} & \\
& $\mathrm{DS}$ & $\mathrm{CV} \%$ & $\mathrm{DS}$ & $\mathrm{CV} \%$ \\
\hline Within run & 0.0643 & 7.41 & 0.0752 & 3.71 \\
Between run & 0.00634 & 7.31 & 0.0190 & 0.94 \\
Overall run & 0.0903 & 10.40 & 0.0776 & 3.82 \\
\hline
\end{tabular}

\section{Specificity}

In 8 alkaline urines no acid $\alpha$-glucosidase was detected with our method, in spite of normal or very high levels of neutral $\alpha$-glucosidase (from 1.05 to $22.55 \mathrm{U} / \mathrm{l}$ ) determined with the Kochmann's method; thus, any interference by neutral $\alpha$-glucosidase in our method can be ruled out.

\section{Comparison with reference method}

We assayed 32 samples for acid $\alpha$-glucosidase activity by our method (y) and the method of Kochmann et al. (x) (11). The following regression equation was obtained: $y=-0.057+0.128 x ; r=0.9893$ (fig. 5).

\section{Preliminary reference values}

We assayed 59 urine samples obtained from carefully selected bealthy adult subjects (46 female and 13 men). The values were obtained on random morning samples. The observed values ranged from 0 to 22.1 $\mathrm{U} / \mathrm{mmol}$ creatinine (fig. 6) (10 percentile $=6.22$ $\mathrm{U} / \mathrm{mmol}$ creatinine and 90 percentile $=15.88$ $\mathrm{U} / \mathrm{mmol}$ creatinine).

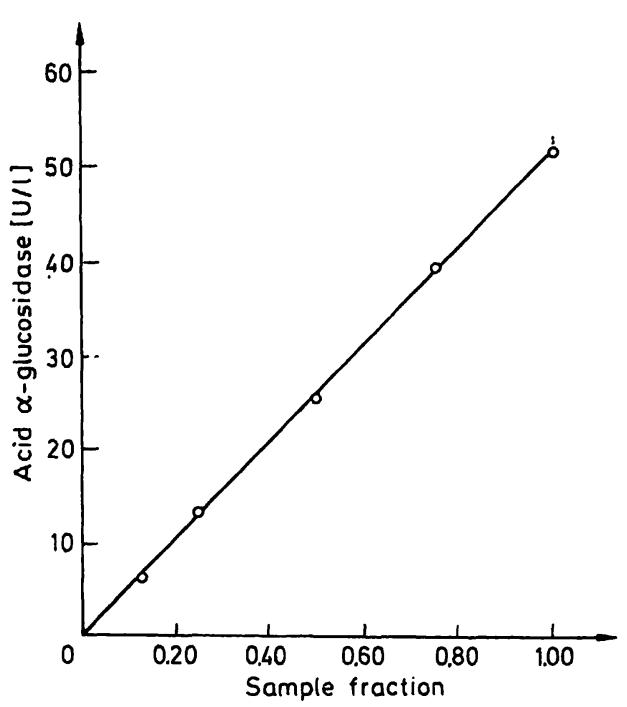

Fig. 4. Linearity of the dilution curve in the proposed method.

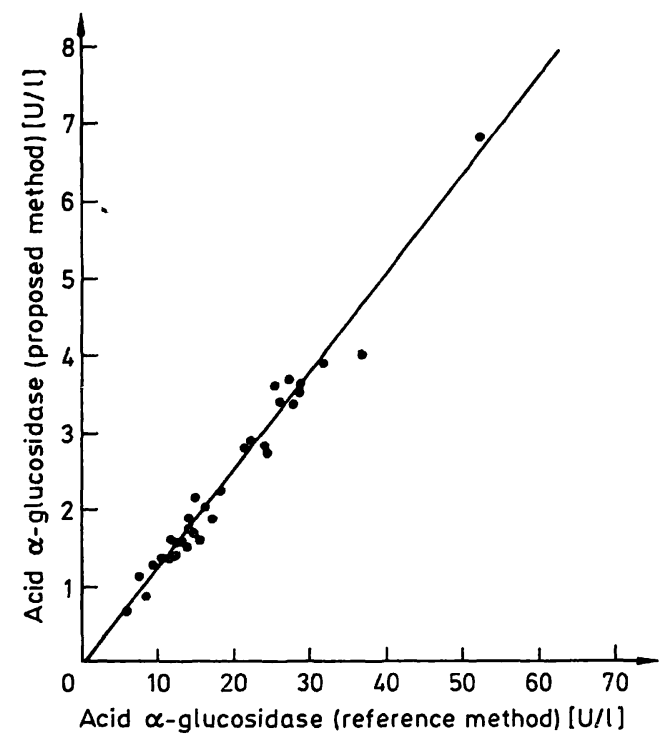

Fig. 5. Correlation between urinary acid $\alpha$-glucosidase activity as assayed by the present method and by the reference method.

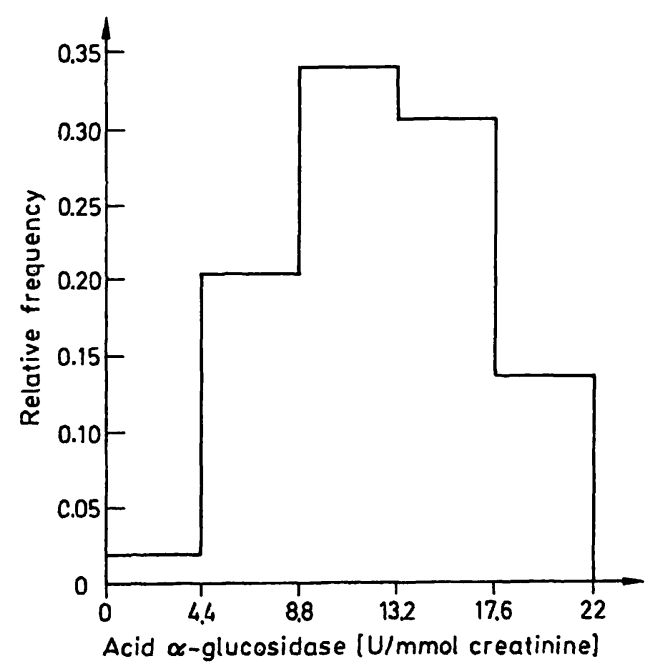

Fig. 6. Frequency distribution of acid $\alpha$-glucosidase activity in 59 adult subjects as measured with the proposed method. 


\section{Conclusions}

The method proposed is simple to operate, and shows high precision coupled to accuracy and specificity, as demonstrated by the good correlation with the reference method and by the absence of response in specimens with $\mathrm{pH}>7.5$ (denaturating condition for acid $\alpha$-glucosidase but not for neutral $\alpha$-glucosidase). We confirm the necessity of sample pretreatment for a better standardization of the method and the importance of standardized storage conditions $\left(-80^{\circ} \mathrm{C}\right.$ or $4{ }^{\circ} \mathrm{C}$, for shorter periods, but not $-20^{\circ} \mathrm{C}$ !) and urine $\mathrm{pH}$ (complete denaturation when $\mathrm{pH}$

\section{References}

1. Bonini, P. A., Ceriotti, G. \& Franzini C. (1970) Clin. Chim. Acta 27, 415-419.

2. Bonini, P. A., Bertolini, D., Masellis, M. \& Ceriotti G. (1971) Riv. Ital. Chir. Plast. III, 219-232.

3. Stroo, W. E. \& Hook, J. B. (1977) Toxicol. Appl. Pharmacol. 39, 423-434.

4. Guanieri, G., Faccini, L., Beltram, E., Chersicla, M., Ianche, M., Lin, S. \& Bazzocchi M. (1979) Proc. 8th Int. Symp. Clin. Enz. 2, 579-600.

5. Plebani, M., Pinton, A., Ceriotti, G., Mazzoleni, F. \& Chiarelli, A. (1981) Gior. It. Chim. Clin. 6, 111-120.

6. Guarnieri, G. Diagnostic value of urinary alpha-glucosidase determination. In "Non invasive diagnosis of kidney disease" (Lubec, G., ed.) Karger, Basel (in press).

7. Salafsky, I. S. \& Nadler, H. L. (1973) J. Lab. Clin. Med. $81,450-454$.

8. Franzini, C. \& Bonini, P. A. (1967) Clin. Chim. Acta 17, 505-510.

9. Dahlqvist, A. (1974) Methoden der enzymatischen Analyse (Bergmeyer, H. U., ed.) 3. Aufl. Vol. 1, pp. 950-957, Verlag Chemie, Weinheim/Bergstr.

10. Brown, B. I. \& Brown, D. H. (1965) Biochim. Biophys. Acta 110, 124-133.

11. Kochmann, G., Kochmann, R., Pape, W., Blank, M. \& Baumann, K. (1983) J. Clin. Chem. Clin. Biochem. 21, 503-509.

12. Ceriotti, G., Franzini, C., Bonini, P. A. \& Gazzaniga, A. (1971) Ann. Ist. Sup. Sanitá 7, 158-185.

13. Ceriotti, G., Bonini, P. A. \& De Negri, M. (1972) La Ricerca Clin. Lab. 2, 29-49.

14. Jaffé, M. (1886) Z. Physiol. Chem. 10, 391-396.

15. Werner, M. \& Gabrielson, D. (1977) Clin. Chem. 23, $700-704$

16. Berscheid, G., Grötsch, H., Hropot, M. \& Klaus E. (1983) J. Clin. Chem. Clin. Biochem. 21, 799-804.

17. Ceriotti, G. \& Bonini, P. A. (1972) Atti II Congr. Soc. It. Biochim. Clin., 685-691.

18. Werner, M. \& Gabrielson, D. (1979) in Burlina and Galzigna Clinical Enzymology Symposia, Piccin Medical Books, Padua 145-158.

19. Pape, W., Kochmann, R., Kochmann, G., Blank, M. \& Baumann, K. (1983) J. Clin. Chem. Clin. Biochem. 21, $511-517$.

20. Kokichi, S., Etsuko, O., Nobuo, S., Kazuhiko, T. \& Tomoichi, K. (1977) Clin. Chim. Acta 77, 61-67.

Dr. F. Ceriotti

Istituto Scientifico

S. Raffaele,

Laboratorio Analisi

Via Olgettina, 60

I-20132 Milan 